\title{
PERSPECTIVE
}

\section{COVID-19 and Face Masks - To Use or Not to Use!}

\section{Devraj Ramakrishnan}

Assistant Professor, Department of Community Medicine, Government Medical College, Idukki, Kerala

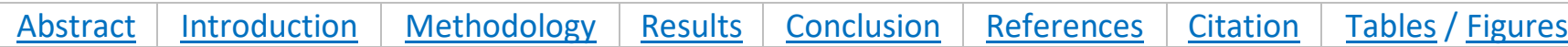

\section{Corresponding Author}

Dr Devraj R, Assistant Professor, Community Medicine, Government Medical College, Idukki, Kerala-685602.

E Mail ID: drdevrajr@gmail.com

\section{Citation}

Ramakrishnan D. COVID-19 and Face Masks - To Use or Not to Use!. Indian J Comm Health. 2020;32(2-Special Issue):240-243.

Source of Funding: Nil Conflict of Interest: None declared

\section{Article Cycle}

Received: 12/04/2020; Revision: 16/04/2020; Accepted: 18/04/2020; Published: 20/04/2020

This work is licensed under a Creative Commons Attribution 4.0 International License.

\section{Abstract}

COVID-19 has evolved into a pandemic in quick time and being a droplet infection, it was quickly understood that prevention is the key. People started to use all types of masks and there was a panic as stocks started running out. Health care workers must use a triple layered surgical mask and those exposed to aerosol generating procedures must use an $\mathrm{N} 95$ mask and these should be kept reserved for them, especially in a resource limited setting. Though initial advice from experts to the general public was not to use a mask in community settings unless they are sick or taking care of someone sick, the advice had to be later modified. Though CDC Atlanta currently advices everyone with no symptoms to wear cloth masks in the community, WHO opines there is no clear evidence to advise for or against mask use in the community. However, WHO encourages countries advising community mask use as it can generate useful evidence. Along with mask use, practicing all other preventive measures such as handwashing, cough etiquette, social distancing, quarantine and isolation are of utmost importance, without which, using surgical masks or even N95 masks, will not be much effective in the community setting.

\section{Keywords}

COVID-19; Face Masks

A cluster of 'pneumonia of unknown cause' cases reported from Wuhan, China evolved into the COVID-19 Pandemic in two months. (1) The agent was identified as a beta-corona virus, initially called novel Corona virus and later named as SARS CoV-2 by International Committee on Taxonomy of viruses.(2) The virus was found to measure $60 \mathrm{~nm}$ to $140 \mathrm{~nm}$ in size and was understood to be spread by droplets and contaminated fomites with a basic reproductive number ( $\mathrm{RO})$ of $2.28(95 \% \mathrm{Cl} 2.06-2.52)$ and a mean incubation period of 5.1 days $(95 \% \mathrm{Cl} 4.5$ -5.8) (2-4)

Being a droplet spread with an R0 of above 2, it was quickly understood that prevention of transmission is the key and WHO called for essential preventive measures like hand washing with soap and water, hand sanitizers, practicing cough etiquette, social distancing, quarantine and isolation. Health workers were asked to use Personal Protective Equipment (PPE) like masks, gowns, goggles and shoe covers while dealing with suspected cases.(5)

The panic set in as the pandemic grew, and many people bought surgical masks and even N95 masks, and started using them regularly while going out, which even led to a shortage of both. Online market places like Amazon and Flipkart had to suspend the sales of masks and hand sanitizers. Road side vendors in India were seen selling surgical masks for twenty to thirty rupees a piece. However, WHO and CDC Atlanta advised general public not to wear masks and the US Surgeon General even made a post on social media which asked the Americans to stop 
buying masks, in the month of March 2020. WHO specifically said that healthy persons have to wear a mask only if they were taking care of a patient suspected to have COVID-19.(6-8) Ministry of Health and Family Welfare (MoHFW), Government of India also endorsed this view.(9) Meanwhile on the social media platforms, the lower incidence of COVID-19 in Japan was attributed to the widespread mask use by the Japanese population, though there were other cultural habits in Japan which might have contributed, like the strong social norms around obedience and hygiene. Also reports surfaced on social media which claimed COVID-19 was indeed airborne and not just a droplet spread and hence universal mask use was a must. These reports were a misinterpreted version of WHO's advice specifically addressing health workers as there was a risk of aerosol generation in health care settings.(10) The European Centre of Disease Prevention and Control and few other experts also opined that wide mask use may give the public a false sense of security, which will lead to a relaxation of other control measures like social distancing and eventually end up causing more harm than good.(11,12) All these led to a state of confusion and panic among general public all over the world regarding whether to use a mask or not. CDC Atlanta modified their advice in April 2020 following reports of asymptomatic carriers spreading the disease and is currently recommending people to wear cloth masks whenever they go out in public, keeping the surgical masks reserved for the health care workers.(13) MoHFW, Government of India also modified their advice and urged the general public to use cloth masks and cover their mouth and nose while going out.(14) WHO released an interim guidance following this which reinforced that the surgical masks and respirators should be reserved for health care workers and if used by the general public, it will create a false sense of security and it will also deplete the stores. WHO, however, said there is no evidence regarding non-surgical masks (cloth masks) to recommend for it or against it. However, WHO strongly encouraged the countries which recommend the use of non-surgical masks in the community as this will enable us to conduct researches on the effectiveness and efficiency of non-surgical masks.(15)

Face masks available in the market can be broadly and loosely divided into three categories -the cloth masks ( technically referred to as non-medical masks or non-surgical masks), the surgical masks ( also referred to as medical masks) and the N95 masks (also referred to as respirators or filtering face piece respirators (FFR) ). The surgical masks are also further divided into two layered and three layered based on its structure. A proper three-layered surgical mask has an outer hydrophobic non-woven layer which repels droplets, blood or even water, a middle melt-blown filter layer which filters microorganisms and an inner soft absorbent nonwoven layer. Non-woven polypropylene, 20 grams per square metre (gsm) made by a spun-bond process is commonly used for the outer and inner layers whereas $25 \mathrm{gsm}$ made by melt-blown technology is used for the filter. Polystyrene, polyethylene, polycarbonate, polyester can also be used. The two layered surgical masks might not have this 25 gsm filter layer which reduces its effectiveness against bacteria and viruses compared to the triple layer mask. The filtration efficiency of a face mask is attributed to three factors- the inertial impaction, diffusion and electrostatic attraction.(1618) N95 masks are designed to closely fit without leaving spaces around the borders like surgical masks which will allow some air to come in through the sides. N95 masks filter out more than $95 \%$ of 0.3 micron particles (hence the name). Very small particles formed as a result of aerosol generating procedures like swab collection, intubation and laboratory processing of specimens might not be effectively blocked by a triple layer surgical mask but only N95 masks. The cloth masks are just one or two layered, mostly made of cotton fabric material. Cloth masks are also stitched in homes using different material which vary widely in their filtration efficacy.(19)

An N95 mask has highest filtration efficacy, followed by a triple layer surgical mask, double layer surgical mask and then the cloth mask. The efficacy of a cloth mask depends on the material used. The pressure drop inside the mask is also an important consideration in the case of cloth masks as a mask should primarily allow the air to come in adequately. Considering both filtration efficacy and pressure drop, the best material for a cloth mask, especially when homemade, was found to be $100 \%$ cotton tshirt material or pillow case material. Though two layered tea towel showed higher efficacy comparable to a surgical mask, the pressure drop was higher inside the mask making breathing difficult. $(19,20)$ A disposable surgical mask or N95 
mask should be discarded after single use and 4-6 hours if continuously used. If the mask gets visibly soiled or moist in between, it should be discarded immediately. But owing to the enormous demand during a pandemic $C D C$ has provided guidelines for extended use and reuse of N95 masks. The surgical masks and respirators should never be washed with soap and water or disinfected with alcohol and reused as it neutralizes the electrostatic charge of the filter layer and compromises its structural integrity which in turn diminishes its filtration efficacy. $(21,22)$ The cloth masks can we washed with soap and water and reused till the fabric is intact.

People touching their face and nose unknowingly with their contaminated hands is another important mode of transmission. An average person touches his face 16 to 24 times an hour. Wearing a mask will help addressing this issue and only a cloth mask will be required for achieving this purpose. $(23,24)$ Beyond ensuring the production and supply chains of face masks for implementing a universal mask use, which is itself a challenge, wearing of a facemask has some cultural and social implications also. Forcing everyone to wear a facemask also has ethical concerns. There are also arguments such as if everyone wears a facemask that will stop the discrimination against patients wearing masks.(8)

\section{Summary}

For preventing droplet transmission from infected individuals, the cloth mask should only be advised as a last resort, if surgical masks are not available; but cloth masks are better than no mask at all. For a health care worker, the double layer surgical mask or a cloth mask, however has less filtration efficacy in preventing the bacteria and especially viruses owing to smaller size, entering from outside, owing to the lack of a high gsm filtration layer. Triple layer surgical face masks are hence advised for those healthcare workers having potential exposure to COVID-19 patients in the outpatient set up.(25) Those health care staff working in COVID-19 Isolation wards are advised to use full set of PPE with N95 masks or a triple layer surgical mask. Only N95 masks along with the full set of PPE are advised for those involved in aerosol generating procedures.(15) For the general public who are healthy, assuming their exposure to the virus is limited in the community setting, N95 masks are not at all required, and surgical masks are not recommended. Theoretically though using a N95 mask or a triple layer surgical mask has more filtration efficacy, practically it would be less efficient owing to our resource limitations as this might make it scarce for the more needy health care workers. They are advised to use a cloth mask. A cloth mask has some filtration efficacy and it will also help them to avoid touching their nose and face unknowingly. If in case they are asymptomatic carriers, it will also help in them not spreading the disease widely. If everyone in the community uses a cloth mask, thus we hope to achieve a reduction in transmission. Along with mask use, practising all other preventive measures such as handwashing, cough etiquette, social distancing, quarantine and isolation are of utmost importance, without which, using surgical masks or even N95 masks will not be much effective in the community setting.

\section{References}

1. Zhou P, Yang X-L, Wang X-G, Hu B, Zhang L, Zhang W, et al. A pneumonia outbreak associated with a new coronavirus of probable bat origin. Nature. 2020;579(7798):270-3.

2. Zhu N, Zhang D, Wang W, Li X, Yang B, Song J, et al. A Novel Coronavirus from Patients with Pneumonia in China, 2019. N Engl J Med. 2020 Feb 20;382(8):72733.

3. Zhang S, Diao M, Yu W, Pei L, Lin Z, Chen D. Estimation of the reproductive number of novel coronavirus (COVID-19) and the probable outbreak size on the Diamond Princess cruise ship: A data-driven analysis. Int J Infect Dis. 2020 Apr 1;93:201-4.

4. Lauer SA, Grantz KH, Bi Q, Jones FK, Zheng $Q$, Meredith HR, et al. The Incubation Period of Coronavirus Disease 2019 (COVID-19) From Publicly Reported Confirmed Cases: Estimation and Application. Ann Intern Med [Internet]. 2020 Mar 10 [cited 2020 Apr 11]; Available from: https://annals.org/aim/fullarticle/2762808/incubati on-period-coronavirus-disease-2019-covid-19-frompublicly-reported

5. Coronavirus [Internet]. [cited $2020 \mathrm{Apr}$ 11]. Available from: https://www.who.int/westernpacific/healthtopics/coronavirus

6. When and how to use masks [Internet]. [cited 2020 Apr 9]. Available from: https://www.who.int/emergencies/diseases/novelcoronavirus-2019/advice-for-public/when-and-howto-use-masks

7. CDC. Coronavirus Disease 2019 (COVID-19) [Internet]. Centers for Disease Control and Prevention. 2020 [cited 2020 Apr 9]. Available from: https://www.cdc.gov/coronavirus/2019ncov/prevent-getting-sick/diy-cloth-facecoverings.html 
8. Feng $S$, Shen $C$, Xia N, Song W, Fan M, Cowling BJ. Rational use of face masks in the COVID-19 pandemic. Lancet Respir Med [Internet]. 2020 Mar 20 [cited 2020 Apr 11];0(0). Available from: https://www.thelancet.com/journals/lanres/article/ PIIS2213-2600(20)30134-X/abstract

9. Corona Virus Disease 2019 (Covid-19) Situation Report - 66 [Internet]. WHO; [cited 2020 Apr 12]. Available from: https://www.who.int/docs/defaultsource/coronaviruse/situation-reports/20200326sitrep-66-covid-19.pdf?sfvrsn=9e5b8b48_2

10. Personal protective measures (non-pharmaceutical) for reducing the risk of acquiring or transmitting human influenza [Internet]. European Centre for Disease Prevention and Control. [cited 2020 Apr 11]. Available from: https://www.ecdc.europa.eu/en/seasonalinfluenza/prevention-and-control/personalprotective-measures

11. Brosseau LM, ScD, Sietsema M, Apr 01 Pl, 2020. COMMENTARY: Masks-for-all for COVID-19 not based on sound data [Internet]. CIDRAP. [cited 2020 Apr 9]. Available from: https://www.cidrap.umn.edu/newsperspective/2020/04/commentary-masks-all-covid19-not-based-sound-data

12. CDC. Coronavirus Disease 2019 (COVID-19) Prevention \& Treatment [Internet]. Centers for Disease Control and Prevention. 2020 [cited 2020 Apr 11]. Available from: https://www.cdc.gov/coronavirus/2019ncov/prevent-getting-sick/prevention.html

13. Advice on the use of masks in the context of COVID19 [Internet]. WHO; [cited 2020 Apr 12]. Available from: https://www.who.int/publicationsdetail/advice-on-the-use-of-masks-in-thecommunity-during-home-care-and-in-healthcaresettings-in-the-context-of-the-novel-coronavirus(2019-ncov)-outbreak

14. How Surgical Masks are Made, Tested and Used [Internet]. [cited $2020 \mathrm{Apr}$ 11]. Available from: https://www.thomasnet.com/articles/other/howsurgical-masks-are-made

15. Surgical Mask : How To CORRECTLY Wear + Remove! [Internet]. Tech ARP. 2020 [cited 2020 Apr 9]. Available from: https://www.techarp.com/science/surgical-maskwear-remove-guide/
16. Read "Reusability of Facemasks During an Influenza Pandemic: Facing the Flu" at NAP.edu [Internet]. [cited 2020 Apr 11]. Available from: https://www.nap.edu/read/11637/chapter/4

17. Davies A, Thompson K-A, Giri K, Kafatos G, Walker J, Bennett A. Testing the Efficacy of Homemade Masks: Would They Protect in an Influenza Pandemic? Disaster Med Public Health Prep. 2013 May $22 ; 7(4): 413-8$.

18. Health $C$ for D and R. N95 Respirators and Surgical Masks (Face Masks). FDA [Internet]. 2020 Apr 5 [cited 2020 Apr 11]; Available from: https://www.fda.gov/medical-devices/personalprotective-equipment-infection-control/n95respirators-and-surgical-masks-face-masks

19. CDC - Recommended Guidance for Extended Use and Limited Reuse of N95 Filtering Facepiece Respirators in Healthcare Settings - NIOSH Workplace Safety and Health Topic [Internet]. 2020 [cited 2020 Apr 9]. Available from: https://www.cdc.gov/niosh/topics/hcwcontrols/reco mmendedguidanceextuse.html

20. Robertson P. Is Washing Masks Effective After Virus Exposure? [Internet]. Smart Air Filters. 2020 [cited 2020 Apr 12]. Available from: https://smartairfilters.com/en/blog/washing-maskseffective-virus/

21. Maclntyre CR, Seale H, Dung TC, Hien NT, Nga PT, Chughtai $A A$, et al. A cluster randomised trial of cloth masks compared with medical masks in healthcare workers. BMJ Open. 2015 Apr 1;5(4):e006577

22. . Robertson P. Is Washing Masks Effective After Virus Exposure? [Internet]. Smart Air Filters. 2020 [cited 2020 Apr 12]. Available from: https://smartairfilters.com/en/blog/washing-maskseffective-virus/

23. Nicas $M$, Best $D$. A study quantifying the hand-to-face contact rate and its potential application to predicting respiratory tract infection. J Occup Environ Hyg. 2008 Jun;5(6):347-52.

24. Kwok YLA, Gralton J, McLaws M-L. Face touching: a frequent habit that has implications for hand hygiene. Am J Infect Control. 2015 Feb;43(2):112-4.

25. Maclntyre CR, Seale $H$, Dung TC, Hien NT, Nga PT, Chughtai $A A$, et al. A cluster randomised trial of cloth masks compared with medical masks in healthcare workers. BMJ Open. 2015 Apr 1;5(4):e006577 